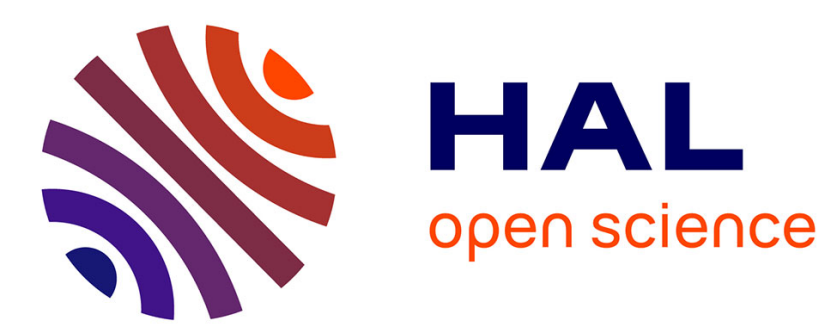

\title{
Apple juice pectic substances
}

Xavier X. Rouau, J.F. Thibault

\section{- To cite this version:}

Xavier X. Rouau, J.F. Thibault. Apple juice pectic substances. Carbohydrate Polymers, 1984, 4 (2), pp.111-125. hal-02725646

\section{HAL Id: hal-02725646 \\ https: / hal.inrae.fr/hal-02725646}

Submitted on 2 Jun 2020

HAL is a multi-disciplinary open access archive for the deposit and dissemination of scientific research documents, whether they are published or not. The documents may come from teaching and research institutions in France or abroad, or from public or private research centers.
L'archive ouverte pluridisciplinaire HAL, est destinée au dépôt et à la diffusion de documents scientifiques de niveau recherche, publiés ou non, émanant des établissements d'enseignement et de recherche français ou étrangers, des laboratoires publics ou privés. 


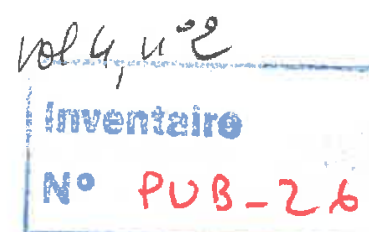

\title{
Apple Juice Pectic Substances
}

\author{
X. Rouau \& J.-F. Thibault
}

Centre de Recherches Agro-Alimentaires, Laboratoire de Biochimie et Technologie des Glucides, 44072 Nantes Cédex, France

(Received: 21 January 1983)

\section{SUMMARY}

Apple juice pectic substances are characterised by a high content of galacturonic acids (75.6\%), a high degree of esterification (83), a low content of neutral sugars $(0.109$ moles/mole of galacturonate residues) and a high molecular weight $\left(\bar{M}_{\mathrm{v}}=95000\right)$. Degradation by heat ( $\beta$-elimination) and by endopolygalacturonase showed that the pectic macromolecules consist of long homogalacturonan regions $192 \%$ of total galacturonides) and of 'hairy' regions in which neutral sugars form long or short side-chains.

\section{INTRODUCTION}

Pectic substances are polyuronides composed mainly of 1,4-linked $\alpha$-D-galacturonic acid (or its methyl ester) with associated neutral sugars, typically galactose and arabinose as neutral side-chains, and 2-linked rhamnose units which are present in the polygalacturonic backbone (Pilnik \& Voragen, 1970; Darvill et al., 1980). They are the major components of the primary cell walls and of the middle lamella of plant tissues, especially those of fruit tissues. Apple juice is rich in dissolved pectins which can suspend other materials in a stable colloidal system (Endo, 1965a). The resultant cloudy juice can be clarified by ultrafiltration (Heatherbell et al., 1977) or, more usually, by an enzymic treatment (Rombouts \& Pilnik, 1978). Thus, the clarification is 111

Carbohydrate Polymers 0144-8617/84/\$03.00-(C) Elsevier Applied Science Puhlishers I.t. England. 1984. Printed in Great Britain 
achieved (i) by the degradation of juice pectins by the combined action of fungal pectinesterases and endopolygalacturonases (Endo, 1965b; Yamasaki et al., 1967) or by the single action of pectin-lyase (Ishii \& Yokotsuka, 1972) or (ii) by the formation of a calcium pectate gel resulting from the addition of fungal pectinesterase and calcium salts (Calvez et al., 1978; Baron et al., 1981). The action of these enzymes has been extensively studied. In contrast, the literature on apple juice pectic substances is very scarce. This paper deals with the chemical composition and some structural features of these pectic substances by means of chemical (alkaline) and endopolygalacturonase degradations.

\section{MATERIALS AND METHODS}

\section{Isolation of pectins}

Ripe apples (S III 5 cultivar) were harvested in 'Station de Recherches Cidricoles' (INRA, Rennes, France) in December 1980. In February 1981 they were cut and pressed with a pack press. The juice yield was 54.6 litres per $100 \mathrm{~kg}$ of apples. Pectins were precipitated with $80 \%$ boiling ethanol. After centrifugation, the precipitate was washed with $70 \%$ ethanol until the eluate was no longer coloured by the anthrone reagent. The precipitate was then solubilised in distilled water, centrifuged at $12000 \mathrm{~g}$ for $15 \mathrm{~min}$ and freeze-dried.

\section{Analyses}

The anhydrogalacturonic acid (AGA) content was measured by the automated $m$-hydroxydiphenyl method (Thibault, 1979). Degrees of methylation (DM) were calculated from the AGA content and the methoxyl content determined colorimetrically (Wood \& Siddiqui, 1971). AGA content and DM were also determined by titration (Schultz, 1965).

Individual neutral sugars were analysed by gas chromatography as their alditol-acetates (Sawardeker et al., 1965). Samples (about $50 \mathrm{mg}$ ) were hydrolysed with $2 \mathrm{~m}$ trifluoroacetic acid at $120^{\circ} \mathrm{C}$ for $1 \mathrm{~h}$ (Albersheim et al., 1967). Total neutral sugars were determined by the orcinol method (Tollier \& Robin, 1979) and values were corrected for the 
interference due to galacturonic acids and results are expressed in arabinose equivalents.

The intrinsic viscosity $\left([\eta], \mathrm{dl} \mathrm{g}^{-1}\right)$ value was obtained at $25^{\circ} \mathrm{C}$ with an Ostwald viscometer (solvent flow time $=93.7 \mathrm{~s}$ ). Pectin was dissolved in $0.155 \mathrm{M} \mathrm{NaCl}$ and $0.005 \mathrm{~m}$ EDTA. The viscosity-average molecular weight $\left(\overline{\mathrm{M}}_{\mathrm{v}}\right)$ was calculated according to Owens et al. (1946).

\section{De-esterification}

Aqueous solutions of pectins $(0.2 \%, \mathrm{w} / \mathrm{v})$ were maintained at $2^{\circ} \mathrm{C}$ in an ice/salt bath and the $\mathrm{pH}$ was adjusted to 13 with $1 \mathrm{M} \mathrm{NaOH}$ at $2{ }^{\circ} \mathrm{C}$. After $1 \mathrm{~h}$, the solution was brought to $\mathrm{pH} 4.5$ with $1 \mathrm{~m} \mathrm{HCl}$. The solution was then dialysed against distilled water and freeze-dried.

\section{$\beta$-elimination}

A sample $(0.5 \%, \mathrm{w} / \mathrm{v})$ in phosphate buffer $(0.1 \mathrm{M}, \mathrm{pH} 6.8)$ was treated at $80^{\circ} \mathrm{C}$ (Albersheim et al., 1960). At appropriate intervals, $0.05 \mathrm{ml}$ of the reaction mixture was diluted with $3 \mathrm{ml}$ of distilled water and the UV absorbance at $235 \mathrm{~nm}$ was measured. The reaction was stopped by adjusting the $\mathrm{pH}$ to 4 with $0.1 \mathrm{M} \mathrm{HCl}$ and the solution was dialysed against distilled water. The percentage of $\alpha(1 \rightarrow 4)$ linkages split was calculated assuming that the molar extinction coefficient for the esterified 4,5-unsaturated galacturonic acid residue is $5500 \mathrm{M}^{-1} \mathrm{~cm}^{-1}$ (Edstroem \& Phaff, 1964).

\section{Hydrolysis by endopolygalacturonase}

A purified endopolygalacturonase (endoPG; EC 3.2.1.15) (Thibault \& Mercier, 1977) was used for the degradation of pectin samples. Reaction mixtures, at $30^{\circ} \mathrm{C}$, contained pectin samples $(0.2 \%$, w/v) in acetate

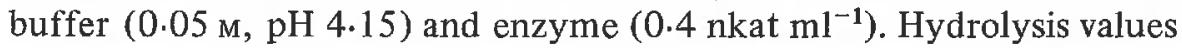
were calculated from the increase of reducing power as determined by the method of Nelson (1944) using galacturonic acid as standard. The reaction was also followed by the decrease of the specific viscosity of the solution, measured with an Ostwald viscometer (solvent flowtime $=82.5 \mathrm{~s}$ ). 


\section{Gel chromatography}

Ion-exchange chromatography was performed on DEAE-SepharoseCL-6B (Pharmacia) columns $(7.5 \times 1.6 \mathrm{~cm})$ equilibrated with sodium acetate buffer (ionic strength $=0.05$ ), $\mathrm{pH} 4.8$. The pectin sample (4 $\mathrm{mg}$ in this buffer) was loaded on to the column and the gel was washed with $50 \mathrm{ml}$ of the buffer at a flow-rate of $40 \mathrm{ml} \mathrm{h}^{-1}$. The bound material was then eluted by a linear sodium acetate gradient at $\mathrm{pH} 4.8$ (ionic strength $=0.05-1 ; 90 \mathrm{ml}$ ) and 3-ml fractions were collected.

Pectins were chromatographed on a Sepharose-CL-2B column $(86 \times 2.6 \mathrm{~cm})$ and after degradation on a Sephadex G-100 column $(80 \times 2.2 \mathrm{~cm})$ and on a Bio-gel P2 column. Elutions on Sepharose-CL2B and on Sephadex G-100 were carried out in ascending direction with sodium acetate buffer (ionic strength $=0.1$ ), $\mathrm{pH} 4.0$, at a flow-rate of $15 \mathrm{ml} \mathrm{h}^{-1}$. Samples of pectin (up to $100 \mathrm{mg}$ ) dissolved in the same buffer were applied to the column and 4-ml fraction, were collected. Results were expressed as a function of $K_{\mathrm{av}}=\left(V_{\mathrm{e}}-V_{0}\right) /\left(V_{\mathrm{t}}-V_{0}\right)$ where $V_{\mathrm{e}}, V_{0}$ and $V_{t}$ are the elution volume of the fraction, the void volume of the column and the total volume of the column, respectively.

Chromatograms were recalculated for $8 \mathrm{mg}$ of injected AGA (Sepharose-CL-2B) and for $2 \mathrm{mg}$ of injected AGA (Sephadex G-100). Chromatography on Bio-gel P2 was performed as described elsewhere (Thibault, 1980). About $1 \mathrm{mg}$ of degraded pectins were injected on to the column and aliquots of the effluent $\left(6 \mathrm{ml} \mathrm{h}^{-1}\right)$ were continuously analysed by the $m$-hydroxydiphenyl and the orcinol methods. Elution profiles represent the absorbance at $520 \mathrm{~nm}$ ( $m$-hydroxydiphenyl detection) and at $425 \mathrm{~nm}$ (orcinol detection) versus elution volume without correction for the interference of AGA during orcinol detection.

\section{RESULTS}

\section{Crude pectins}

The AGA content of the apple juice was $1.2 \mathrm{mg} \mathrm{ml}^{-1}$. The pectins were recovered by precipitation with $80 \%$ ethanol. Ion-exchange chromatography on DEAE-Sepharose-CL-6B (Fig. 1) showed that only $1 \%(\mathrm{w} / \mathrm{w})$ of this material was not bound to the gel. The gradient in acetate released the pectic substances in a single peak containing both AGA and neutral sugars in a constant ratio throughout the peak. 


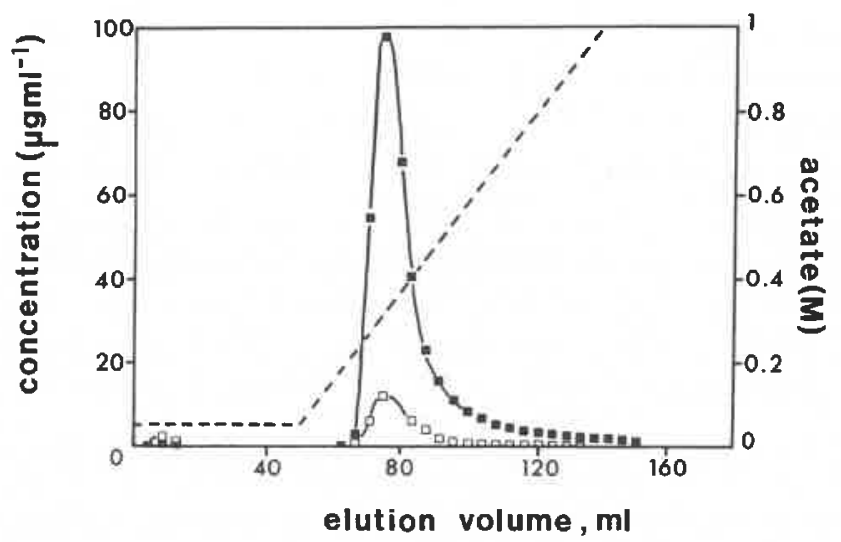

Fig. 1. Ion-exchange chromatography of apple juice pectins on DEAE-SepharoseCL-6B. The column is first washed with sodium acetate buffer (ionic strength $=$ $0.05), \mathrm{pH}$ 4.8. Bound material was eluted by a linear sodium acetate gradient at $\mathrm{pH} 4.8$ (ionic strength $=0.05-1 ; 90 \mathrm{ml}$ ). $\square$, Neutral sugars; $=$, galacturonic acids.

The chemical composition is shown in Table 1. The apple juice pectin is characterised by a high AGA content $(75.6 \%$ by the $m$-hydroxydiphenyl method, $76.2 \%$ by titration) and a high DM ( 83.0 from the colorimetric determination of methoxyl groups, 85.2 by titration). The neutral sugar content is 0.109 moles/mole of galacturonate residues. Arabinose and galactose, in approximately equal amounts,

\section{TABLE 1}

Chemical Composition of Apple Juice Pectins

(Molar ratio of components to galacturonic acid)

\begin{tabular}{lccc}
\hline \multicolumn{1}{c}{ Component } & $\begin{array}{c}\text { Crude } \\
\text { pectin }\end{array}$ & $\begin{array}{c}\text { De-esterified } \\
\text { pectin }\end{array}$ & $\begin{array}{c}\text { Pectin after } \\
\text {-elimination }\end{array}$ \\
\hline Galacturonic acid & 100 & 100 & 100 \\
Rhamnose & 0.9 & 0.7 & 0.7 \\
Arabinose & 5.2 & 4.3 & 5.0 \\
Xylose & 0.2 & 0.2 & 0.2 \\
Galactose & 4.3 & 2.6 & 3.4 \\
Glucose & 0.3 & 0.3 & 0.3 \\
Methanol & 83.0 & $<2.0$ & 36.0 \\
\hline
\end{tabular}


account for $78 \%(\mathrm{w} / \mathrm{w})$ of total neutral sugars. Xylose and glucose appear as minor constituents while mannose has not been detected. These sugars are known to form side-chains linked to the main chain via C-2 or C-3 of galacturonic acid and presumably via the C-4 of rhamnose units (Pilnik \& Voragen, 1970; Darvill et al., 1980). From the rhamnose content, it can be calculated that there is one 'kink' (Rees \& Wight, 1971) per 116 galacturonic acid residues. Viscosity measurements led to an intrinsic viscosity value of $6.6 \mathrm{dl} \mathrm{g}^{-1}$, corresponding to a viscosity-average molecular weight of 95000 . The Huggins coefficient was 0.47 .

The fractionation of apple juice pectins by gel-permeation chromatography on Sepharose-CL-2B (Fig. 2(a)) demonstrated that they have large hydrodynamic volumes and a wide molecular weight distribution. The pectic fraction eluted at the void volume of the column, accounting for $3 \%$ of the total material, is richer in neutral sugars (molar ratio AGA/neutral sugars, as arabinose $=1 \cdot 5 / 1$ ) than the main peak (AGA/ neutral sugars $=7 \cdot 6 / 1)$ eluted at $K_{\text {av }}=0.56$. The fraction at the void

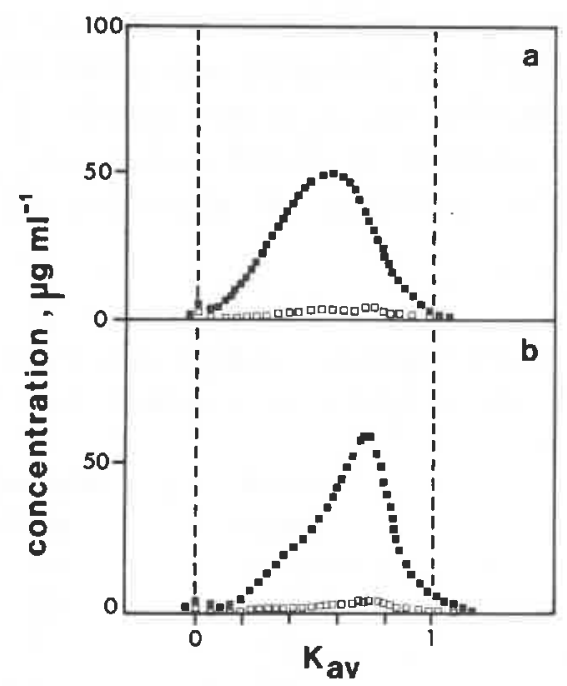

Fig. 2. Gel-permeation chromatography on Sepharose-CL-2B of apple juice pectins. Crude pectin (a) and alkali de-esterified pectin (b) were applied to a Sepharose-CL-2B column $\left(V_{0}=180 \mathrm{ml} ; V_{\mathbf{t}}=480 \mathrm{ml}\right)$ equilibrated with sodium acetate buffer (ionic strength $=0.1$ ), $\mathrm{pH} 4.0$. $\square$, Neutral sugars; $\mathbf{m}$, galacturonic acids. 
volume $\left(K_{\mathrm{av}}<0.1\right)$, the pectic molecules with lowest molecular weight $\left(K_{\mathrm{av}}>0.5\right)$ and the intermediate population $\left(0.1<K_{\mathrm{av}}<0.5\right)$ have DM values of 80,90 and 75 , respectively.

\section{Enzymic degradation of the de-esterified crude pectin}

Pectins were alkali de-esterified. Conditions were chosen in order to minimise chain cleavages by $\beta$-elimination (Albersheim et al., 1960). Gel-permeation on Sepharose-CL-2B (Fig. 2(b)) of the de-esterified pectin shows that there is only a slight increase in the $K_{\mathrm{av}}$ of the main peak $\left(K_{\mathrm{av}}=0.70\right)$. No intrinsic viscosity value could be obtained because of the insolubility of the pectate in the $0.155 \mathrm{M} \mathrm{NaCl}$ medium used for the measurements. The chemical composition of the deesterified pectin is indicated in Table 1. The DM is less than 2 and the neutral sugar composition is close to that of the crude pectin, except for galactose, some of which is lost.

The resultant pectate was degraded by an endopolygalacturonase (endoPG). The course of degradation was monitored by the increase of reducing groups and by the decrease of specific viscosity of the solution. The reaction was stopped at $25 \mathrm{~h}$. The percentage of hydrolysis and the decrease of specific viscosity were $30 \%$ and $94 \%$, respectively (Fig. 3 ).

The reaction mixture was chromatographed on Sephadex G-100 and on Bio-gel P2. On Sephadex G-100 (Fig. 4(a)) the degraded pectate was

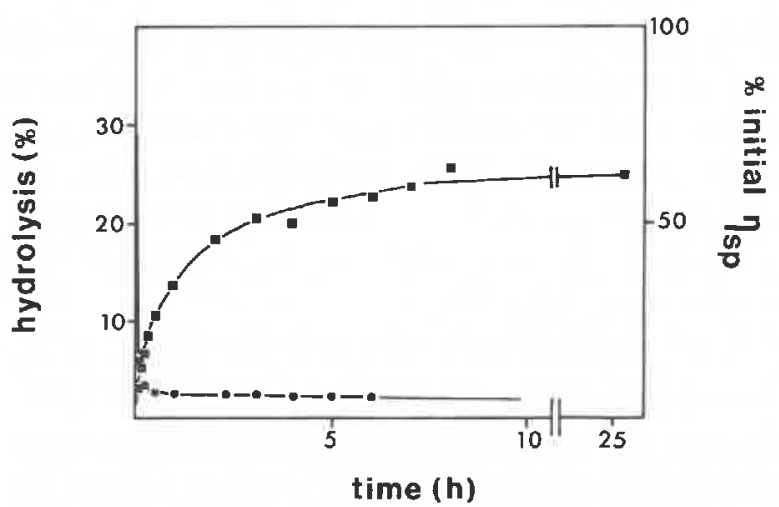

Fig. 3. Enzymatic degradation of de-esterified pectin. Percentage hydrolysis ( $₫)$ by endopolygalacturonase was calculated from the increase in reducing groups; specific viscosity (•) was measured and expressed as \% of initial specific viscosity. 


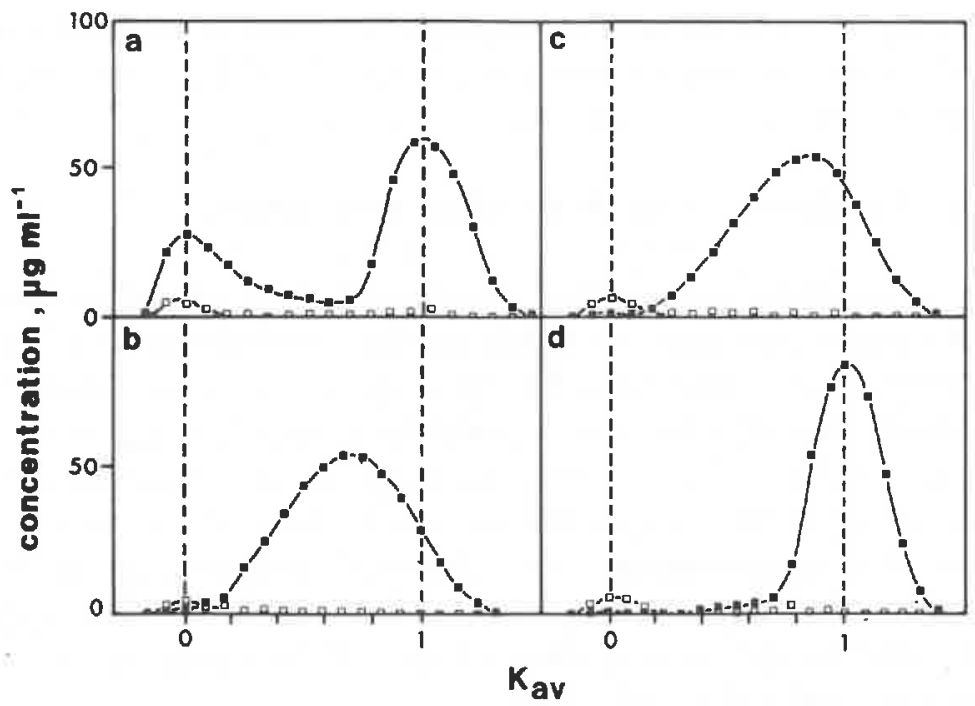

Fig. 4. Gel-permeation chromatography on Sephadex G-100 of degraded pectins. Samples were applied to a Sephadex G-100 column $\left(V_{0}=45 \mathrm{ml} ; V_{\mathrm{t}}=113 \mathrm{ml}\right)$ equilibrated by sodium acetate buffer (ionic strength $=0.1$ ), $\mathrm{pH} \mathrm{4.0}$. $\square$, Neutral sugars; $₫$, galacturonic acids. (a) Pectin after de-esterification and endopolygalacturonase degradation; (b) pectin after $\beta$-elimination; (c) pectin after $\beta$-elimination and endopolygalacturonase degradation; (d) pectin after $\beta$-elimination, de-esterification and endopolygalacturonase degradation.

eluted in two peaks: one at the void volume of the column accounting for $22 \%$ and $57 \%$ of total AGA and neutral sugars, respectively, and the other at the total volume representing $78 \%$ and $43 \%$ of total AGA and neutral sugars. On Bio-gel P2 (Fig. 5(a)), the same reaction mixture was separated in a series of peaks $1,2, \ldots, 7$ with the same elution volumes as oligogalacturonides of degree of polymerisation of $1,2, \ldots, 7$, and material excluded from the column.

Effluents were continuously detected for their AGA content ( $m$ hydroxydiphenyl method) and for their neutral sugar or AGA content (orcinol method). For each peak, the ratio between the area obtained from the orcinol detection and the area obtained from the $m$-hydroxydiphenyl detection were calculated. The peaks 1-7 are characterised by a constant ratio equal to that obtained under the same conditions for a galacturonic acid standard, indicating that these peaks correspond to 


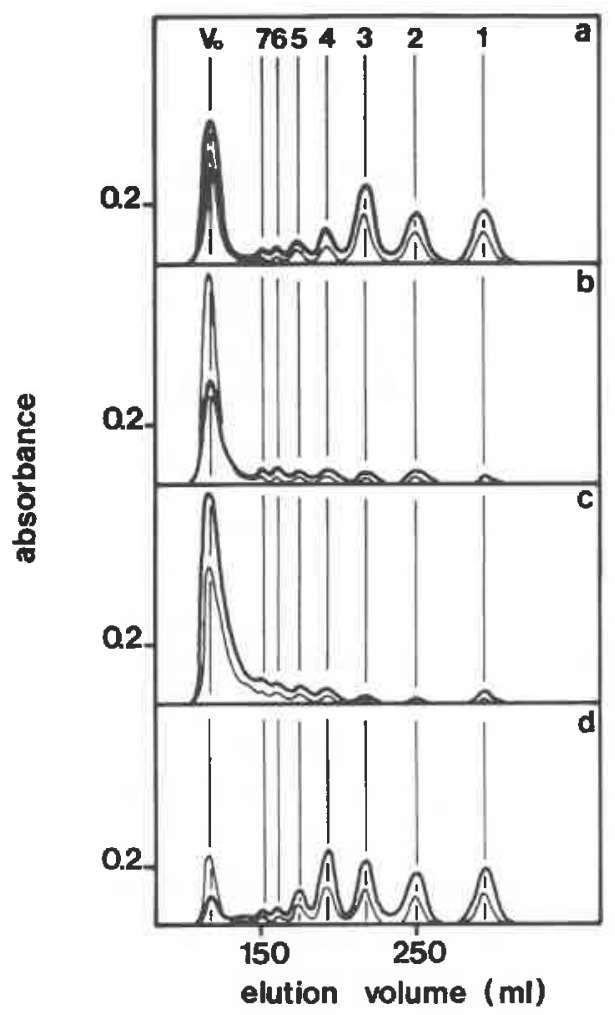

Fig. 5. Gel-permeation chromatography of degraded pectins on Bio-gel P2. Samples were loaded on to a Bio-gel P2 column $(203 \times 2 \mathrm{~cm})$ equilibrated at $65^{\circ} \mathrm{C}$ with sodium acetate buffer (ionic strength $=0.1$ ), $\mathrm{pH} \mathrm{3.6.} \mathrm{The} \mathrm{eluate} \mathrm{was} \mathrm{con-}$ tinuously analysed: ( - absorbance at $520 \mathrm{~nm}$ ( $m$-hydroxydiphenyl method) and (-) absorbance at $420 \mathrm{~nm}$ (orcinol method). $V_{0}=$ void volume; numbers $1-7$ refer to degree of polymerisation of oligogalacturonides. (a) Pectin after de-esterification and endopolygalacturonase degradation; (b) products obtained after dialysis of $\beta$-eliminated pectin; (c) pectin after $\beta$-elimination and endopolygalacturonase degradation; (d) pectin after $\beta$-elimination, de-esterification and endopolygalacturonase degradation.

true oligogalacturonides, accounting for $68 \%$ of total AGA. In contrast, material eluted at the void volume contains AGA (32\% of the total) and all the neutral sugars.

The material eluted at the void volume of the Sephadex G-100 column is necessarily excluded from the Bio-gel P2 column. Therefore 
combined results of these two chromatograms show that products from pectin after de-esterification and endo-PG-degradation can be divided into three classes: oligogalacturonides, from the Bio-gel P2 elution pattern and material containing both AGA and neutral sugars but different by their hydrodynamic volumes from the Sephadex G-100 and Bio-gel P2 fractionations. The intermediate-molecular-weight product ( $10 \%$ of total AGA, $43 \%$ of total neutral sugars) contains 0.3 moles of neutral sugars/mole of AGA while the high-molecularweight fragments ( $22 \%$ of total AGA, $57 \%$ of total neutral sugars) have 0.2 moles of neutral sugars/mole of AGA.

\section{Enzymic degradations of $\beta$-eliminated pectins}

Crude pectins were submitted to $\beta$-elimination by heat treatment. The resultant 4,5-unsaturated galacturonides were estimated by UV absorption (Fig. 6). After $4 \mathrm{~h}$, the reaction was stopped and it was calculated that $11 \%$ of the $\alpha-(1 \rightarrow 4)$ linkages were split.

The low-molecular-weight products $(20 \% \mathrm{w} / \mathrm{w}$ of $\beta$-eliminated products) obtained after dialysis were chromatographed on Bio-gel P2 (Fig. 5(b)). Of the total AGA, 5.1\% was eluted as pure oligogalacturonides. Non-dialysable material was applied to a Sephadex G-100 column (Fig. 4(b)) and separated into two populations: a high-molecular-weight fraction eluted at the void volume of the column (1.3\% of total AGA, $50 \%$ of the total neutral sugars) with 5 moles of neutral sugars/mole of

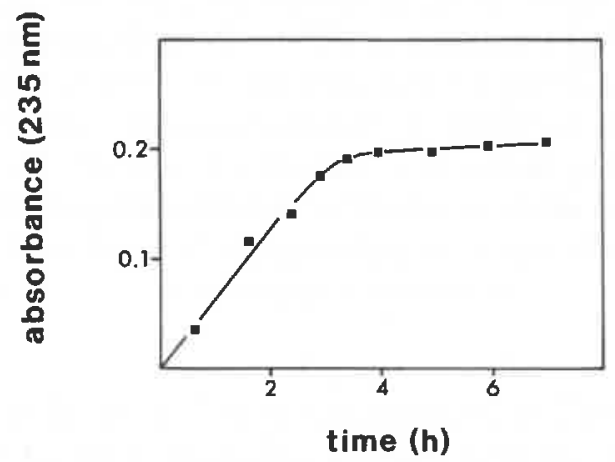

Fig. 6. Kinetics of $\beta$-elimination of pectins. Pectins were dissolved in $0.1 \mathrm{M}$ phosphate ouffer, $\mathrm{pH} 6.8$, at $80^{\circ} \mathrm{C}$. At appropriate intervals, $0.05 \mathrm{ml}$ of the reaction mixture were diluted with $3 \mathrm{ml}$ of distilled water and UV absorption at $235 \mathrm{~nm}$ was measured. 
AGA and an intermediate-molecular-weight fraction eluted at $K_{\mathrm{av}}=0.7$ (93.6\% of the total AGA, 50\% of the total neutral sugars) containing 0.1 moles of neutral sugars/mole of AGA. The non-dialysable material was recovered and analysed (Table 1); the composition was quite similar to the crude pectin except for the DM which was reduced to 36 . Chromatography on Sephadex G-100 showed that the distribution of the methoxyl groups was not regular since the material at the void volume $\left(K_{\mathrm{av}}<0.1\right)$, the intermediate-molecular-weight fraction $(0.1<$ $\left.K_{\mathrm{av}}<0.5\right)$ and the low-molecular-weight products $\left(K_{\mathrm{av}}>0.5\right)$ have DM values of $54 \cdot 1,37.7$ and 27.2 , respectively.

The $\beta$-eliminated pectin was submitted to endoPG degradation. Hydrolysis was very low $(<5 \%)$. As above, products were separated into three classes using Sephadex G-100 (Fig. 4(c)) and Bio-gel P2 (Fig. 5(c)) chromatographies: pure oligogalacturonides ( $22 \%$ of total AGA), intermediate-molecular-weight fragments $(76.5 \%$ of total AGA, $43 \%$ of total neutral sugars) with a molar ratio neutral sugars/AGA less than 0.1 and high-molecular-weight fractions (1.5\% of the total AGA, 57\% of the total neutral sugars) containing 3.6 neutral sugars residues/AGA.

The $\beta$-eliminated pectin was then alkali de-esterified. Gel-permeation chromatography on Sephadex G-100 showed that the de-esterification led to very slight depolymerisation since the $K_{\mathrm{av}}$ is increased from 0.7 to only 0.8 . The $\beta$-eliminated and de-esterified pectin has the same neutral sugars/AGA molar ratio as the parent pectin but the DM is 12.6 . This material was further degraded by endoPG to $33 \%$ hydrolysis and products from pectin after $\beta$-elimination, de-esterification and endoPGdegradation were analysed by gel-permeation on Sephadex G-100 (Fig. 4(d)) and Bio-gel P2 (Fig. 5(d)). The products can be separated as above into three classes: pure oligogalacturonides accounting for $92 \%$ of total AGA, an intermediate-molecular-weight fraction (7.7\% of total AGA, $50 \%$ of total neutral sugars) with 1.1 moles of neutral sugars/mole of AGA and high-molecular-weight fragments containing $0.3 \%$ of total AGA and $50 \%$ of total neutral sugars (molar ratio of 26.3 neutral sugars/AGA).

\section{DISCUSSION}

Pectins are the major component of the alcohol-insoluble material of apple juice since the DEAE-Sepharose-CL-6B column is able to bind as 
much as $99 \%$ of this material. Apple juice pectins are very large molecules with a high AGA content $(75.6 \%$ ), a low content of neutral sugars (6.8\%) with equal amounts of arabinose and galactose, and a high DM (83). They differ from many other apple pectic fractions by their very low content of neutral sugars. For example, the 'soluble-polymethylgalacturonate' (Knee, 19.78), the acid-extracted (Barrett \& Northcote, 1965) and the water-soluble (O'Beirne et al., 1981) pectic fractions have neutral sugar contents of $0.302, \cong 0.2$ and $0.139 \mathrm{moles} / \mathrm{mole}$ of AGA, respectively. Apple juice pectins are quite similar to the EDTAsoluble pectins, i.e. neutral sugars/AGA molar ratio of 0.06 (O'Beirne et al., 1981). However, Knee (1973) pointed out that increasingly insoluble pectins contain increasing amounts of neutral sugars, and de Vries et al. (1981) reported that pectins with the lowest neutral sugar content (neutral sugar/AGA $=0.167, \mathrm{w} / \mathrm{w}$ ) and the highest DM (80) were extracted at room temperature by a $0.05 \mathrm{M}$ acetate buffer (pH 5.2). A very high DM seems to be a characteristic for apple juice pectins (Peynaud, 1951; Endo, 1965a).

The apple juice pectins have been degraded by heat ( $\beta$-elimination) and endoPG after de-esterification. $\beta$-elimination reaction occurs with a simultaneous de-esterification since the DM was reduced to 36 . These two reactions are competitive: when too many methyl esters are hydrolysed, the electronic environment hinders further $\beta$-elimination Albersheim et al., 1960; BeMiller \& Kumari, 1972). This fact explains why only $11 \%$ of the $\alpha-(1 \rightarrow 4)$ linkages of the pectin were split after $\beta$-elimination.

Results from gel-permeation chromatography of $\beta$-eliminated pectins indicate a non-regularly repeating structure. Half of the neutral sugars are concentrated on only $1.3 \%$ of total AGA and eluted at the void volume of the Sephadex G-100 column. These results suggest the presence of long side-chains in 'hairy' regions along with 'smooth" regions consisting mainly of non-substituted galacturonan. Similar results were found for $\beta$-eliminated pectic substances from apple (Barrett \& Northcote, 1965), from soy sauce (Kikuchi \& Sugimoto, 1976), or from enzyme-degraded apple pectic substances (de Vries et al., 1982).

In order to have more information on the 'hairy' and 'smooth' regions, degradations with an endopolygalacturonase have been carried out. This enzyme hydrolyses $\alpha-(1 \rightarrow 4)$ linkages between anhydrogalacturonic acids and therefore de-esterification was carried out on 
crude pectin and on $\beta$-eliminated pectin. The residual DM was less than 2 for the crude de-esterified pectin and 12.6 for the $\beta$-eliminated deesterified pectin. Whistler \& BeMiller (1958) reported that a methyl ester close to a 4,5-double bond is more resistant to saponification. Alkali treatment leads to only a slight decrease in molecular weight and some loss in galactose content. This latter fact was not explained. The pectin after $\beta$-elimination and de-esterification was more readily degraded by the enzyme than the crude de-esterified pectin, as shown by the extent of hydrolysis and chromatographic separation. This fact could be explained by steric hindrance of endoPG action by side-chains. In contrast, the hydroxyl ions might be able to split linkages between galacturonic acids in the 'hairy' regions, leading to the production of new substrates for the enzyme. The products from $\beta$-eliminated, deesterified and endoPG-degraded pectin are predominantly pure galacturonides (92\% of total AGA). Neutral sugars form side-chains, concentrated on less than $8 \%$ of the AGA which can be divided into two classes according to the molar ratio of $\mathrm{AGA} /$ neutral sugars. Since endoPG is not able to hydrolyse trigalacturonic acid (Thibault \& Mercier, 1978), it can be assumed that there are at least four continuous AGA residues between two side-chains. It can therefore be calculated that the mean degree of polymerisation of long side-chains is about 100 and that of short side-chains is about 4. From our results, it cannot be concluded that these two side-chains have a different chemical composition. Nevertheless, from the literature data, xylose is known to be present as single units or short side-chains (Bouveng, 1955; de Vries et al., 1983; Kikuchi \& Sugimoto, 1976), while longer side-chains are formed by branched arabinose residues and/or galactose residues (de Vries et al., 1983; Knee et al., 1975).

\section{ACKNOWLEDGEMENTS}

The authors wish to thank Dr J. F. Drilleau and Dr A. Baron (Station de Recherches Cidricoles, I.N.R.A., Le Rheu, France) for the preparation of pectins and Dr F. M. Rombouts (Agricultural University of Wageningen, The Netherlands) for helpful discussions during the preparation of the manuscript. 


\section{REFERENCES}

Albersheim, P., Neukom, H. \& Deuel, H. (1960). Arch. Biochem. Biophys. 90, 46. Albersheim, P., Nevins, D. J., English, P. D. \& Karr, A. (1967). Carbohydr. Res. 5, 340.

Baron, A., Prioult, C. \& Drilleau, J. F. (1981). Sci. Aliments 1, 81.

Barrett, A. J. \& Northcote, D. H. (1965). Biochem. J. 94, 617.

BeMiller, J. N. \& Kumari, G. V. (1972). Carbohydr. Res. 25, 419.

Bouveng, H. D. (1965). Acta Chem. Scand. 19, 953.

Calvez, J., Baron, A. \& Drilleau, J. F. (1978). C. R. Acad. Agric. 63, 1196.

Darvill, A., McNeil, M., Albersheim, P. \& Delmer, D.P. (1980). In The Biochemistry of plants, ed. N. E. Colbert, Vol. 1, New York and London, Academic Press, pp. 101-16.

de Vries, J. A., Voragen, A. G. J., Rombouts, F. M. \& Pilnik, W. (1981). Carbohydr. Polymers 1, 117.

de Vries, J. A., Rombouts, F. M., Voragen', A. G. J. \& Pilnik, W. (1982). Carbohdyr. Polymers 2, 25.

de Vries, J. A., Den Uijl, C. H., Voragen, A. G. J., Rombouts, F. M. \& Pilnik, W. (1983). Carbohydr. Polymers 3, 193.

Edstroem, R. D. \& Phaff, H. J. (1964). J. Biol. Chem. 239, 2409.

Endo, A. (1965a). Agric. Biol. Chem. 29, 137.

Endo, A. (1965b). Agric. Biol. Chem. 29, 229.

Heatherbell, D. A., Short, J. L. \& Strubi, P. (1977). Confructa 22, 157.

Ishii, S. \& Yokotsuka, T. (1972). J. Agr. Fd Chem. 20, 787.

Kikuchi, T. \& Sugimoto, H. (1976). Agric. Biol. Chem: 40, 87.

Knee, M. (1973). Phytochem. 12, 637.

Knee, M. (1978). Phytochem. 17, 1257.

Knee, M., Fielding, A. M., Archer, S. A. \& Laborda, F. (1975). Phytochem. 14, 2213.

Nelson, N. (1944). J. Biol. Chem. 153, 375.

O'Beirne, D., Van Buren, J. P. \& Mattick, L. R. (1981). J. Fd Sci. 47, 173.

Owens, H. S., Lotzkar, H., Schultz, T. H. \& Maclay, W. D. (1946). J. Am. Chem. Soc. 68, 1628.

Peynaud, E. (1951).Ind. Agr. Alim. 609.

Pilnik, W. \& Voragen, A. G. J. (1970). In The biochemistry of fruits and their products, ed. A. C. Hulme, Vol. 1, New York, Academic Press, pp. 53-87.

Rees, D. A. \& Wight, A. W. (1971). J. Chem. Soc. (B), 1366.

Rombouts, F. M.\& Pilnik, W. (1978). Process Biochem. 13, 9.

Sawardeker, J. S., Sloneker, J. H. \& Jeanes, A. (1965). Analyt. Chem. 37, 1602.

Schultz, T. H. (1965). Determination of the degree of esterification of pectin. In Methods in carbohydrate chemistry, ed. R. L. Whistler, Vol. 5, New York and London, Academic Press, pp. 189-94. 
Thibault, J. F. (1979). Lebensm. Wiss. u. Technol. 12, 247.

Thibault, J. F. (1980). J. Chromatogr. 194, 247.

Thibault, J. F. \& Mercier, C. (1977). J. Solid-Phase Biochem. 2, 295.

Thibault, J. F. \& Mercier, C. (1978). J. Fd Biochem. 2, 379.

Tollier, M. T. \& Robin, J. P. (1979). Ann. Technol. Agric. 28, 1.

Whistler, R. L. \& BeMiller, J. N. (1958). Adv. Carbohydr. Chem. 9, 289.

Wood, P. J. \& Siddiqui, I. R. (1971). Analyt. Biochem. 39, 418.

Yamasaki, M., Kato, A., Chu, S. Y. \& Arima, K. (1967). Agric. Biol. Chem. 31, 552. 
